\title{
FREKUENSI DAN FAKTOR RISIKO KUNJUNGAN ANTENATAL CARE
}

\section{Frequency And Factor Effecting Of Antenatal Care Visit}

\author{
Sari Priyanti ${ }^{1}$, Dian Irawati ${ }^{2}$, Agustin Dwi Syalfina ${ }^{3}$ \\ ${ }^{123}$ STIKes Majapahit \\ achazhilasari@gmail.com
}

\section{Riwayat Artikel}

Diajukan: Feb 2020

Diterima: Maret 2020

\section{Penulis Korespondensi:}

- Sari Priyanti

- STIKes Majapahit

-achazhilasari@gmail.com

\section{Kata Kunci:}

Faktor Risiko, Frekuensi, Kunjungan, Antenatal Care

\begin{abstract}
ABSTRAK
Antenatal care merupakan program yang mampu menurunkan angka kematian ibu dan bayi. Program antenatal care mampu mendeteksi secara dini komplikasi sejak kehamilan diikuti dengan pendidikan kesehatan dan pencegahan komplikasi kehamilan. Standar frekuensi kunjungan antenatal care berdasarkan rekomendasi WHO pada tahun 2016 adalah 8 kali. Penelitian bertujuan untuk menganalisis faktor risiko yang berpengaruh terhadap frekuensi kunjungan antenatal care. Penelitian yang digunakan adalah studi epidemiologi analitik dengan pendekatan cross sectional. Variabel dependent adalah ibu hamil di puskesmas dan variabel independent adalah usia, pendidikan, pekerjaan, pendapatan keluarga, paritas, persepsi, dukungan keluraga, dukungan suami, pengetahuan. Jumlah sampel yang diperoleh dari hasil perhitungan rumus simple random sampling adalah 140. Setelah data dikumpulkan, diolah kemudian dianalisis univariate, biavariate, multivariate. Hasil uji statistik meunjukkan bahwa faktor risiko yang berpengaruh terhadap frekuensi kunjungan antenatal care adalah paritas ( $\mathrm{PR}=2,453 ; 95 \% \mathrm{CI}=1,129-5,331 ; P$ value $=0,023)$ dan pengetahuan $(\mathrm{PR}$ $=5,114 ; 95 \% \mathrm{CI}=1,878-13,922 ; P$ value $=0,001)$. Pengetahuan baik ibu hamil tentang pemeriksaan kehamilan maka kunjungan kehamilan antenatal care dengan jumlah kunjungan $\geq 6$ kali. Semakin tinggi pemahaman ibu tentang pentingnya pemeriksaan kehamilan untuk kesehatan ibu dan bayi maka perilaku untuk mendapatkan pelayanan kesehatan untuk kehamilan semakin baik. Bagi petugas kesehatan diharapkan menerapkan standar frekuensi kunjungan ANC sesuai dengan standar WHO 2016 dan meningkatkan pengetahuan ibu tentang kehamilan sampai dengan keluarga berencan melalui kelas ibu hamil.
\end{abstract}

Kata Kunci : faktor risiko, frekuensi, kunjungan, antenatal care

\section{ABSTRACT}

Antenatal care is a program that can reduce maternal and infant mortality. Antenatal care program is able to detect complications early in pregnancy followed by health education and prevention of pregnancy complications. The standard frequency of antenatal care visits based on WHO recommendations in 2016 is 8 times. The study aims to analyze the risk factors that influence the frequency of antenatal care visits. The research used was an analytic epidemiological study with a cross sectional approach. The dependent variable was pregnant women at the puskesmas and the independent variables were age, education, 
occupation, family income, parity, perception, family support, husband support, knowledge. The number of samples obtained from the calculation of the simple random sampling formula is 140. After the data was collected, it was processed and then analyzed univariate, biavariate, multivariate. Statistical test results show that risk factors that influence the frequency of antenatal care visits are parity $(P R=2,453 ; 95 \% C I$ $=1,129-5,331 ;$ Pvalue $=0.023)$ and knowledge $(P R=5,114 ; 95 \% C I=1,878-13,922 ;$ Pvalue $=0.001)$. Good knowledge of pregnant women about antenatal care checks then antenatal care pregnancy visits with the number of visits $\geq 6$ times. The higher the mother's understanding of the importance of antenatal care for maternal and infant health, the better behavior to get health services for pregnancy. Health workers are expected to apply the ANC visit frequency standard in accordance with WHO 2016 standards and increase maternal knowledge about pregnancy to family planning through pregnant mother classes.

Keywords : risk factor, frekuency, visits, antenatal care

\section{PENDAHULUAN}

Era Sustainable Development Goals (SDGs) diawali pada tahun 2016 dengan salah satu program untuk menurunkan morbiditas dan mortalitas yang berhubungan dengan kehamilan yang capaiannya masih sangat tinggi di seluruh dunia. The World Health Organization (WHO) memiliki visi bahwa setiap ibu hamil dan bayi baru lahir harus mendapatkan perawatan yang berkualitas sejak kehamilan sampai dengan nifas. Antenatal care berperan penting dalam memberikan perawatan yang berkualitas karena dalam antenatal care mengandung komponen promosi kesehatan, skrining, diagnosis dan pencegahan penyakit.

Perkembangan pada pelayanan antenatal care memberikan kesempatan pada ibu hamil untuk berkomunikasi serta member dukungan kepada ibu. Komunikasi yang efektif tentang masalah fisiologis, biomedis, perilaku dan sosiokultural, serta dukungan yang efektif, termasuk dukungan sosial, budaya, emosional dan psikologis kepada wanita hamil mampu memberikan pengalaman positif selama kehamilan dan persalinan sebagai pondasi untuk mewujudkan ibu yang sehat.

Menurut WHO, program antenatal care (ANC) pada tahun 2002 yaitu kunjungan antenatal care dilakukan 4 kali terdiri dari kunjungan pertama pada umur kehamilan kurang dari 12 minggu, kedua pada umur kehamilan \pm 26 minggu, ketiga pada umur kehamilan \pm 32 minggu dan keempat pada umur kehamilan \pm 38 minggu. Program ini mengalami perkembangan pada tahun 2016, kunjungan pemeriksaan kehamilan dengan standar 8 kali kunjungan sebagai upaya menurunkan angka kematian perinatal dan kualitas perawatan pada ibu. 8 kali kunjungan antenatal care ditetapkan berdsarkan riset dan meliputi kontak pertama dengan petugas kesehatan pada umur kehamilan \pm 12 minggu, kedua pada umur kehamilan \pm 20 minggu, kontak ketiga pada umur kehamilan \pm 26 minggu, kontak ke empat umur kehamilan \pm 30 minggu, kontak ke lima umur kehamilan \pm 34 minggu, kontak ke enam umur kehamilan \pm 36 minggu, kontak ke tujuh umur kehamilan \pm 38 minggu dan kontak ke delapan pada umur kehamilan 40 minggu (WHO, 2016). Berikut tabel perbedaan progam antenatal care WHO Tahun 2002 dan 2016

\begin{tabular}{|c|c|}
\hline $\begin{array}{l}\text { Tabel Perbedaan } \\
\text { Antenatal Care }\end{array}$ & Kunjungan \\
\hline $\begin{array}{l}2002 \text { WHO Focused } \\
\text { ANC MODEL }\end{array}$ & $\begin{array}{c}2016 \text { WHO ANC } \\
\text { MODEL }\end{array}$ \\
\hline \multicolumn{2}{|c|}{ Trimester I } \\
\hline $\begin{array}{l}\text { Kunjungan 1: } \\
\text { 8-12 minggu }\end{array}$ & $\begin{array}{l}\text { Kontak 1: } \\
\text { Sampai dengan } 12\end{array}$ \\
\hline
\end{tabular}




\begin{tabular}{lc}
\hline & minggu \\
\hline Kunjungan 2: & Krimester II \\
24-26 minggu & Kontak 2: 20 minggu \\
& Trimester II \\
\hline Kunjungan 3: & Kontak 4: 30 minggu \\
32 minggu & Kontak 5: 34 minggu \\
Kunjungan 4: & Kontak 6: 36 minggu \\
36-38 minggu & Kontak 7: 38 minggu \\
\multicolumn{2}{c}{ Kontak 8: 40 minggu } \\
\hline \multicolumn{2}{c}{ Kembali periksa untuk persalinan pada umur } \\
kehamilan 41 minggu belum melahirkan \\
\hline Sumber: $(W H O, 2016)$
\end{tabular}

Capaian kunjungan kehamilan di seluruh dunia meningkat dari $40,9 \%$ pada tahun 1990 menjadi $58,6 \%$ pada tahun 2013. Kunjungan kehamilan di negara berkembang capaiannya sebesar $48,1 \%$ pada tahun 2013 , angka ini jauh lebih rendah daripada negara maju sebesar 84.8\%. Capaian kunjungan awal kehamilan pada trimester 1 sebesar $24 \%$ di negara berkembang dan $81,9 \%$ pada negara maju (Moller, et al., 2017)

Antenatal care bertujuan untuk memantau dan meningkatkan kesejahteraan ibu dan bayi janin. Strategi WHO untuk menurunkan kehamilan risiko tinggi melalui perawatan rutin untuk semua wanita, perawatan tambahan untuk wanita dengan penyakit penyerta dalam kategori sedang dan komplikasi, perawatan obstetrik dan neonatal khusus untuk wanita dengan penyakit penyerta yang berat dan komplikasi. antenatal care merupakan perawatan selama kehamilan yang cukup efektif untuk menjalankan program WHO tersebut. Menurut penelitian Yeoh et al, 2016 bahwa 26\% ibu dengan kehamilan risiko tinggi tidak pernah melakukan kunjungan pemeriksaan kehamilan sedangkan $80 \%$ wanita hamil tanpa komplikasi kehamilan melakukan pemeriksaan kehamilan yang teratur. Wanita hamil yang tidak pernah melakukan kunjungan antenatal mengalami komplikasi kehamilan yaitu korioamnionitis dan solusio plasenta serta 9,18 kali berisiko melahirkan bayi dengan berat badan rendah, 12,05 kali berisiko terjadi kematian janin dan 10,03 kali berisiko dengan kematian neonatal (Raatikainen, et al., 2007). Jumlah kunjungan antenatal memiliki hubungan signifikan terhadap berat badan bayi lahir rendah, wanita dengan kunjungan kehamilan lebih 6 kali kunjungan antenatal memilki berat badan lahir 727,26 g lebih berat dari ibu dengan 1-3 kunjungan kehamilan dan 325,88 g lebih berat daripada mereka yang memiliki 4-5 kunjungan (Khatun \& Rahman, 2007). Berdasarkan latar belakang tersebut maka pada penelitian ini bertujuan untuk menganalisis faktor risiko kunjungan antenatal care.

\section{METODE}

Penelitian ini menggunakan jenis penelitian epidemiologi analitik dengan metode cross sectional. Variabel tergantung adalah kunjungan antenatal care. Kunjungan antenatal care di bagi menjadi 2 kriteria kurang dari mean dan lebih dari sama dengan mean. Mean kunjungan kehamilan dari seluruh responden adalah 6 kali kunjungan. Variabel bebas meliputi usia, pendidikan, paritas, pekerjaan, pendapatan keluarga, pengetahuan, dukungan suami, dukungan keluarga dan persepsi. Nilai Mean dari pendapatan keluarga adalah Rp 1.625.000,- Populasi yang digunakan seluruh ibu hamil di UPT Puskesmas Dlanggu pada bulan September sampai dengan Desember 2019. Jumlah sampel 140 responden yang diperoleh dengan menggunakan teknik simple random sampling. Data diambil di poli KIA UPT Puskesmas Dlanggu dengan menggunakan kuesioner. Setelah data terkumpul diolah dan dianalisis dengan menggunakan chisquare untuk analisis bivariat dan regresi logistic untuk uji multivariate

\section{HASIL DAN PEMBAHASAN HASIL}

Usia ibu sebagian besar dalam rentang 20 sampai dengan 35 tahun yaitu $86(61,4 \%)$ sedangkan ibu yang berusia $<20$ tahun dan $>35$ tahun sejumlah $54(38,6 \%)$. Ibu yang berusia 20-35 tahun memiliki proporsi yang sama antara yang melakukan kunjungan kehamilan kurang dari 6 dan lebih dari sama dengan 6 kali. Begitupula frekuensi kunjungan kehamilan ibu dengan usia $<20$ tahun dan $>35$ tahun antara frekuensi kunjungan $<6$ dan $\geq 6$ kali kunjungan juga berproporsi sama. Sehingga hasil analisis bivariat menunjukkan usia ibu tidak memiliki hubungan signifikan 
dengan frekuensi kunjungan ANC $(\mathrm{PR}=1,209$; $95 \%$ CI $=0,602-1,135 ; P$ value $=0,224)$

Tabel 1 Distribusi Frekuensi Variabel Karakteristik dan frekuensi ANC

\begin{tabular}{lcc}
\hline \multicolumn{1}{c}{ Variabel } & F & \% \\
\hline Usia Ibu & & \\
<20 tahun dan >35 tahun & 54 & 38,6 \\
20-35 tahun & 86 & 61,4 \\
\hline Pendidikan & & \\
Rendah & 34 & 24,3 \\
Tinggi & 106 & 75,7 \\
\hline Pekerjaan & & \\
Tidak bekerja (IRT) & 75 & 53,6 \\
Bekerja & 65 & 46,4 \\
\hline Pendapatan keluarga/bulan & & \\
<Mean & 44 & 31,4 \\
$\geq$ Mean & 96 & 68,6 \\
\hline Paritas & & \\
Berisiko (1 dan $\leq 5)$ & 75 & 53,6 \\
Tidak berisiko (2-4) & 65 & 46,4 \\
\hline Persepsi tentang & & \\
pemeriksaan kehamilan & & \\
Negatif & 95 & 67,9 \\
Teratur & 45 & 32,1 \\
\hline Dukungan keluarga & & \\
Kurang mendukung & 82 & 58,6 \\
Mendukung & 58 & 41,4 \\
\hline Dukungan suami & & \\
Kurang mendukung & 106 & 75,7 \\
Mendukung & 34 & 24,3 \\
\hline Pengetahuan ibu tentang & & \\
pemeriksaan kehamilan & & \\
Kurang baik \\
baik
\end{tabular}

Sumber: Data Primer

Pendidikan ibu dibagi menjadi 2 yaitu pendidikan rendah dan tinggi. Pendidikan rendah jika lulusan pendidikan terakhir ibu SD-SMP dan pendidikan tinggi apabila pendidikan terakhir SMUPerguruan tinggi. Sebagian besar ibu memiliki pendidikan dalam kategori tinggi sebesar 106 responden $(75,7 \%)$. Ibu yang berpendidikan rendah sebesar 34 (24,3\%). Ibu dengan pendidikan rendah dan tinggi memiliki proporsi yang sama antara frekuensi kunjunga kurang dari 6 dan lebih dari 6 kali kunjungan sehingga hasil analisis dengan menggunakan chi square tidak menunjukkan ada hubungan signifikan pendidikan dengan frekuensi kunjungan ANC $(\mathrm{PR}=1,262 ; 95 \%$ $\mathrm{CI}=0,536-1,169 ; P$ value $=0,205)$

Sebagian besar ibu memiliki pekerjaan sebagai ibu rumah tangga yaitu 75 responden $(53,6 \%)$ dan 65 responden $(46,4 \%)$ bekerja selain menjadi ibu rumah tangga untuk memperoleh penghasilan tiap bulannya. Ibu yang berperan sebagai ibu rumah tangga dan memperoleh upah berproporsi yang sama antara frekuensi kunjungan kehamilan $<6$ dan $\geq 6$ kali. Hasil analisis bivariat diperoleh pendidikan ibu bukan faktor risiko frekuensi kunjungan ANC kurang dari 6 kali $(P R=0,209 ; 95 \%$ $\mathrm{CI}=0,896-1,630 ; P$ value $=1,208)$

Ibu hamil memiliki pendapatan kelurga per bulannya lebih dari sama dengan rata-rata pendapatan seluruh responden ( $\mathrm{Rp}$ 1.625.000) sebesar 96 responden $(68,6 \%)$ dan yang memiliki pendapatan kurang dari Rp 1.625 .000 sejumlah 44 respoonden $(31,4 \%)$. Pendapatan keluarga tidak berhubungan signifikan dengan frekuensi kunjungan ANC karena tidak menunjukkan proporsi yang berbeda antara pendapatan keluarga $<\operatorname{Rp} 1.625 .000$ dan $\geq \operatorname{Rp} 1.625 .000$ (OR = 1,010; $\quad 95 \% \quad \mathrm{CI}=0,739-1,380$; $P$ value $=0,950)$

Dilihat dari aspek paritas diperoleh paritas ibu lebih dari 50\% termasuk paritas primigravida dan grande multi sebesar 75 $(53,6 \%)$ dan 65 responden $(46,4 \%)$. Pada penelitian ini paritas ibu berhubungan signfikan dengan frekuensi kunjungan antenatal care. Ibu multigravida 1,536 kali lebih berisiko melakukan kunjungan kehamilan kurang dari 6 kali selama kehamilan dibandingkan ibu primigravida dan grandemulti $(\mathrm{PR}=1,536 ; 95 \%$ $\mathrm{CI}=1,026-2,300 ; P$ value $=0,031)$.

Persepsi ibu tentang pemeriksaan kehamilan dibagi menjadi negatif dan 
positif. Persepsi ibu dalam kategori negative sebesar 95 responden $(67,9 \%)$ dan persepsi positif sebesar 45 responden $(32,1 \%)$. Proporsi kunjungan kehamilan antara persepsi tentang pemeriksaan kehamilan kriteria positif dan negative adalah sama. Pada penelitian ini persepsi ibu tentang pemeriksaan kehamilan tidak berhubungan dengan rendahnya kunjungan antenatal care $(\mathrm{PR}=1,096 ; 95 \%$ $\mathrm{CI}=0,675-1,232 ; P$ value $=0,558$ ).

Dukungan keluarga kepada ibu untuk melakukan kunjungan kehamilan dibagi menjadi 2 yaitu kurang mendukung dan mendukung. Presentase dukungan keluarga antara yang kurang mendukung dan mendukunng adalah $82(58,6 \%)$ dan 58 $(41,4 \%)$. Dukungan keluarga dengan kriteria kurang mendukung memiliki kurang dari 6 kali kunjungan kehamilan sebesar 49 (35\%) dan lebih dari sama dengan 6 kali sebesar $33 \quad(23,6 \%)$ sedangkan keluarga yang mendukung untuk melakukan pemeriksaan kehamilan 30 responden $(21,4 \%)$ melakukan $<6$ kali kunjungan dan 28 responden (20\%) dengan $\geq 6$ kali pemeriksaan kehamilan. Uji bivariate antara dukungan keluarga dengan frekuensi kunjungan ANC diperoleh tidak memiliki hubungan signifikan ( $\mathrm{PR}=1,155$; 95\% CI=0,851-1,568; $P$ value $=0,345$ ).

Dukungan suami sebagian besar termasuk kategori kurang mendukung dalam melakukan kunjungan kehamilan adalah $106(75,7 \%)$ dan sebagian kecil dalam kategori mendukung adalah 34 $(24,3 \%)$. Frekuensi kunjungan pemeriksaan kehamilan antara dukungan suami yang kurang mendukung dan yang mendukung menunjukkan tidak ada perbedaan dalam presentasenya sebesar $61(43,6 \%)$ dan $45(32,1 \%)$ untuk yang kurang mendukung sedangkan dukungan suami yang mendukung 18(12,9\%) melakukan pemeriksaan kehamilan sebanyak $<6$ dan $16(11,4 \%) \geq 6$ kali kunjungan pemeriksaan kehamilannya. Dukungan suami bukan merupakan faktor risiko berpengaruh terhadap frekuensi kunjungan ANC $(\mathrm{PR}=$ 1,087; $\quad 95 \% \quad \mathrm{CI}=0,761-1,553$; $P$ value $=0,637)$.

Sebagian besar ibu memiliki pengetahuan baik tentang pemeriksaan ANC yaitu $103 \mathrm{ibu}(73,6 \%)$ dan $37(26,4 \%)$ berpengetahuan kurang baik tentang ANC. Ibu berpengetahuan kurang baik $24(17,1 \%)$ dengan kunjungan ANC lebih dari sama dengan 6 kali dan 13(16,5\%) kurang dari 6 kali kunjungan sedangkan ibu berpengetahuan baik hampir 50\% melakukan kunjungan ANC < 6 kali yaitu $66(47,1 \%)$ dan $37(26,4 \%)$ dengan kriteria $\geq 6$ kali untuk frekuensi pemeriksaan kehamilannya. Ibu memiliki pengetahuan baik tentang pentinganya datang memeriksakan kehamilan kepada petugas kesehatan karena mendapatkan informasi dari kelas ibu hamil yang diadakan oleh bidan desa. Pada penelitian ini pengetahuan ibu tentang pemeriksaan ANC berhubungan signifkan terhadap frekuensi kunjungan ANC ( $\mathrm{PR}=1,824 ; 95 \% \mathrm{CI}=0,346-0,870$; $P$ value $=0,002)$. Setelah dilakukan uji multivariate seluruh variabel dengan frekuensi kunjungan antenatal care diperoleh hasil faktor risiko yang paling dominan berpengaruh adalah paritas $(\mathrm{PR}=$ 2,$453 ; \quad 95 \% \quad \mathrm{CI}=1,129-5,331$; $P$ value $=0,023)$ dan pengetahuan $(\mathrm{PR}=$ 5,$114 ; \quad 95 \% \quad \mathrm{CI}=1,878-13,922$; $P$ value $=0,001)$.

\section{PEMBAHASAN}

Usia ibu ketika hamil mempengaruhi kunjungan ibu untuk memeriksakan kehamilan kepada petugas kesehatan. Usia kurang dari 20 tahun ketika hamil ada rasa malu untuk memeriksakan kehamilannya karena kehamilan itu diakibatkan pernikahan dini dimasa remaja dan kurang kesiapan mental dalam menghadapi kehamilannya sedangkan usia 20-35 tahun hampir seluruhnya patuh untuk ANC sehingga usia berhubungan dengan 
kepatuhan ibu untuk datang memeriksakan kehamilan (Putri, et al., 2015). Namun pada penelitian ini menunjukkan usia tidak berhubungan dengan frekuensi kunjungan ANC karena antara wanita hamil dengan usia berisiko dan tidak berisiko memiliki perilaku pemeriksaan kehamilan yang sama antara yang jumlah kunjungan kurang dari 6 dan lebih dari sama dengan 6. Hasil ini sama dengan penelitian Harahap \& Siregar, 2014 bahwa usia tidak berpengaruh signifikan terhadap pemeriksaan kehamilan. Ibu hamil berumur 35 tahun tidak rutin melakukan pemeriksaan kehamilan karena ada rasa malu menganggap dirinya sudah tidak pantas lagi untuk hamil dalam usia >35 tahun serta anak mereka banyak dan sudah besar.

Pendidikan merupakan suatu proses melalui pengajaran atau pelatihan yang mamou meningkatkan perkembangan mental, emosional dan intelektual individu. Dengan tingginya pendidikan, ibu hamil akan lebih mudah menghadapi dan mengatasi setiap perubahan psikologis maupun fisiologis selam kehamilan karena tingginya pemahaman terhadap informasi kesehatan yang didapat serta akan meningkatkan juga keinginan dalam melakukan pemeriksaan kehamilan demi kesehatan ibu dan bayi dalam kandungan. Penelitian ini menunjukkan pendidikan tidak berhubungan dengan frekuensi kunjungan ANC presentasi frekuensi kunjungan ibu $<6$ kali dan $\geq 6$ kali pada ibu berpendidikan tinggi tidak ada beda. Hasil ini sama dengan penelitian Laminullah, et al., 2015 tingkat pendidikan tidak berhubungan dengan kepatuhan kunjungan ANC, sebagian besar ibu berpendidikan tinggi tidak patuh dalam melakukan kunjungan ANC. Berbeda dengan penelitian Syalfina, 2015 pendidikan berpengaruh terhadap kualitas antenatal care. Rendahnya pendidikan menyebabkan kualitas antenatal care ibu hamil kurang baik.
Pekerjaan secara umum didefinisikan sebagai suatu aktifitas individu di luar pekerjaan rumah tangga untuk memperoleh uang yang digunakan untuk menunjang kebutuhan rumah tangga. Pekerjaan bukan faktor risiko yang signifikan terhadap frekuensi kunjungan ANC. Pekerjaan menunjang kemampuan ibu hamil untuk dapat melakukan pemeriksaan kehamilan baik dari segi biaya maupun waktu. Ibu rumah tangga tidak mamu menjangkau pelayanan untuk memeriksakan kehamilan berhubungan dengan keterbatasan biaya sedangkan ibu hami yang bekerja di luar rumah mengalami kesulitan karena kurangnya waktu untuk datang ke bidan atau dokter untuk periksa kehamilan. Menurut Dahiru \& Oche, 2015 status pekerjaan ibu sebagai pekerja merupakan faktor protektif yang meningkatkan kunjungan ANC lebih dari sama dengan 4 kali selama kehamilan (OR=0,91; 95\% CI=0,87-0,96).

Pendapatan keluarga merupakan total seluruh uang yang diperoleh oleh semua anggota keluarga dari bekerja untuk pemenuhan semua anggota keluarga termasuk kebutuhan kesehatan. Semakin tinggi tingkat kekayaan ibu hamil maka semakin besar untuk melakukan kunjungan kehamilan sebaliknya semakin rendah tingkat kekayaannya maka semakin tinggi untuk tidak melakukan kunjungan ANC (Fagbamigbe \& Idemudia, 2015). Hasil uji bivariat penelitian ini diperoleh pendapatan keluarga tiap bulan bukan faktor yang berisiko untuk tingginya frekuensi kunjungan ANC wanita hamil. Menurut penelitian Afulani, 2015 tingkat kekayaan ibu berpengaruh sangat kuat terhadap tingginya kualitas ANC yang dinilai dari pertama kali kunjungan ANC dilakukan sedini mungkin dan jumlah kunjungan ANC yang lebih dari sama dengan 4 kali kunjungan. Status sosial ekonomi mempengaruhi kunjungan ANC bukan dari waktu melakukan kunjungan namun tempat 
dan jumlah kunjungan untuk memeriksakan kehamilannya. Status sosial ekonomi tinggi sebagian besar memeriksakan kehamilan di fasilitias kesehatan swasta (klinik, rumah sakit) sedangkan status sosial ekonomi rendah melakukan pemeriksaan kehamilannya di puskesmas dan rumah sakit umum (Tenkorang, 2016).

Paritas menunjukkan jumlah kehamilan yang pernah dialami dan memberikan pengalaman ibu dalam menghadapi kehamilan. Apabila ibu multi gravida atau grande multi memiliki pengalaman kehamilan normal pada kehamilan sebelumnya maka ibu akan lebih tidak rutin dalam melakuka kunjungan ANC karena akan menerapkan penanganan yang diperoleh paada kehamilan terdahulu dalam menghadapi perubahan fisik maupun psikis pada kehamilan ini. Penelitian ini membuktikan bahwa paritas tidak berpengaruh signifikan terhadap frekuensi kunjungan ANC. Ibu primigravida dan grande multi lebih banyak dalam melakukan kunjungan ANC begitu pula yang jarang melakukan kunjungan ANC sehingga hasil analisis menunjukkan paritas bukan merupakan faktor risiko. Hasil ini sejalan dengan Nurmawati \& Indrawati, 2018 yaitu paritas tidak berhubungan signifikan dengan cakupan kunjungan ANC dikarenakan proporsi cakupan kunjungan ANC yang baik tidak jauh berbeda antara primigravida dan multi gravida begitu pula sebaliknya cakupan kunjungan ANC yang kurang baik memiliki presentasi yang hampir sama antara multigravida dan primigravida.

Persepsi ibu tentang pemeriksaan kehamilan merupakan bentuk penafsiran dan pemberian arti tentang pentingnya pemeriksaan kehamilan bagi kesehatan diri sendiri dan janin dalam kandungan. Berdasaran uji bivariat dengan chi square, persepsi ibu tentang pemeriksaan kehamilan tidak berpengauh signifikan terhadap frekuensi kunjungan ANC. Meskipun sebagian besar responden dengan persepsi negative dan sebagian kecil berpersepsi positif tapi tidak menunjukkan perbedaan pada presentasi terhadap masing2 kriteria frekuensi kunjungan. Menurut penelitian Ermaya, et al., 2015 tingkat persepsi ibu yang baik maka akan diikuti dengan tingginya keteraturan dalam melakukan pemeriksaan kehamilan sehingga dalam penelitiannya menunjukkan hubungan kuat antara persepsi dengan keteraturan pemeriksaan kehamilan.

Dukungan keluarga dan dukungan suami juga tidak berpengaruh signifikan pada penelitian ini. Meskipun lebih dari 50\% keluarga kurang mendukung dan sebagian besar suami kurang mendukung dalam kunjungan ANC. Kurang mendukunganya keluarga dalam kunjungan ANC dilihat dari aspek mendampingi ibu hamil ketika melakukan kunjungan ANC serta kurang dalam memberikan informasi tentang kehamilan. Dukungan orang terdekat dari wanita hamil seperti suami, ibu, kakak dan saudara lainnya berdampak positif bagi ibu untuk rutin memeriksakan kehamilan dan menghadapi perubahan fisik dan psikis tiap triwulan. Penting sekali untuk meningkatkan pengetahuan keluarga dan suami tentang kehamilan sampai dengan nifas. Keterlibatan suami dan keluarga dalam pengambilan keputusan tentang pelayanan kesehatan selama kehamilan meningkatkan frekuensi kunjungan kehamilan dan menjadi salah satu faktor yang berpengaruh terhaap kunjungan ANC (Bhowmik, et al., 2020)

Pengetahuan ibu tentang antenatal care sebagai faktor yang berpengaruh terhadap perilaku ibu hamil untuk memeriksakan kehamilan. Hasil penelitian ini membuktikan pengetahuan ibu berpengaruh signifikan terhadap frekuensi kunjungan ANC. Menurut Fitriyani, et al., 2016 yaitu pengetahuan memiliki 
hubungan signifikan dengan kelengkapan kunjungan ANC. Ibu hamil berpengetahuan kurang menyebabkan ketidak lengkapan kunjungan ANC sedangkan kelengkapan kunjungan ANC dilakukan ibu berpengetahuan baik. Pengetahuan baik akan berdampak pada tingginya motivasi wanita hami untuk berkunjung ke petugas kesehatan periksa kehamilan

\section{KESIMPULAN}

Pengetahuan dan paritas merupakan faktor risiko yang paling berpengaruh terhadap frekuensi kunjungan ANC. Setelah dilakukan uji dengan memasukkan seluruh variabel, besar faktor risiko pengetahuan sebagai faktor yang berpengaruh terhadap frekuensi kunjungan ANC menjadi lebih besar dan kuat. Ibu dengan pengetahuan kurang baik 5,114 kali berisiko memiliki frekuensi kunjungan ANC < 6 kali dibandingkan ibu berpengetahuan baik. Frekuensi kunjungan ANC menggunakan standar mean yaitu 6 kali tetapi rekomendasi WHO tahun 2016 standar frekuensi kunjungan kehamilan adalah 8 kali.

\section{DAFTAR PUSTAKA}

Afulani, P. A., 2015. Rural/Urban And Socioeconomic Differentials In Quality Of Antenatal Care In Ghana. Plos one Journal, 10(2), pp. 1-28.

Bhowmik, K. R., Das, S. \& Isla, M. A., 2020. Modelling The Number Of Antenatal Care Visits In Bangladesh To Determine The Risk Factors For Reduced Antenatal Care Attendance. Plos One Journal, 15(1), pp. 1-17.

Dahiru, T. \& Oche, O. M., 2015. Determinants Of Antenatal Care, Institutional Delivery And Postnatal Care Services Utilization In Nigeria. Pan African Medical Journal, 21(321), pp. 1-17.

Ermaya, N., Nugroho, D. \& Dharminto, 2015. Pengaruh Motivasi Dan
Persepsi Pelayanan Terhadap Keteraturan Antenatal Care Pada Ibu Hamil di Puskesmas Ngemplak Simongan Kota Semarang Pada triwulan I Tahun 2015. Jurnal Kesehatan Masyarakat, 3(3), pp. 8898.

Fagbamigbe, A. F. \& Idemudia, E. S., 2015. Barriers To Antenatal Care Use In Nigeria:Evidences From NonUsers And Implications For maternal Health Programming. BMC Pregnancy and Childbirth, 15(95), pp. 1-10.

Fitrayeni, Suryati \& Faranti, R. M., 2016. Penyebab Rendahnya Kelengkapan Kunjungan Antenatal Care Ibu Hamil Di Wilayah Kerja Puskesmas Pegambiran. Jurnal Kesehatan Masyarakat Andalas, 10(1), pp. 101107.

Harahap, R. \& Siregar, M., 2014. Pengaruh Karakteristik Ibu Dan Dukungan Suami Terhadap Pemeriksaan Kehamilan Di Kecamatan Angkola Timur Kabupaten Tapanuli Selatan. Jurnal Ilmiah PANNMED, 8(3), pp. 317-325.

Khatun, S. \& Rahman, M., 2007. Quality Of Antenatal Care And Its Dose Response Relationship With Birth Weigth In A Maternal And Child health Training Institute In Bangladesh. Journal Biosocial Science, Volume 40, pp. 321-337.

Laminullah, L., Kandou, G. \& Rattu, A., 2015. Faktor-Faktor Yang Berhubungan Dengan Kunjungan Pemeriksaan Antenatal Care K4 di Puskesmas Sipatana Kota Gorontalo. JIKMU, 5(4), pp. 323-336.

Moller, A. B., Petzold, M., Chou, D. \& Say, L., 2017. Early Antenatal Care Visit: A Systematic Analysis Of Regional And Global Levels And Trends Of Coverage From 1990 to 
2013. The Lancet Global Health, 5(10), pp. e977-e983.

Nurmawati \& Indrawati, F., 2018. Cakupan Kunjungan Antenatal Care Pada Ibu Hamil. HIGIEA Journal Of Publich Health, 2(1), pp. 112-124.

Putri, S. D. K., Christiani, N. \& Nirmasari, C., 2015. Hubungan Usia Ibu Hamil Dengan Kepatuhan ANC Di Puskesmas Suruh Kabupaten Semarang. Jurnal Keperawatan Maternitas, 3(1), pp. 33-41.

Raatikainen, K., Heiskanen, N. \& Heinonen, S., 2007. Under-Attending Free Antenatal Care Is Associated With Adverse Pregnancy Outcomes. Journal BMC Public Health, 1(268), pp. 1-8.

Syalfina, A. D., 2015. Faktor Risiko Kualitas Antenatal Care. Surabaya, Politeknik Kesehatan Kementrian Kesehatan Surabaya.

Tenkorang, E. Y., 2016. Type Of Health Facility And Utilization Of Antenatal Care Services Among Ghanaian Women. Population Research and Policy Review, 35(5), pp. 631-650.

WHO, 2016. WHO Recommendations On Antenatal Care For A Positive Pregnancy Experience. Luxembourg: World Health Organization.

Yeoh, P. L., Hornetz, K. \& Dahlui, M., 2016. Antenatal Care Utilisation And Content Between Low-Risk And High-Risk Pregnant Women. Journal Plos One, 11(3), pp. 1-17. 